\section{RSP}

http://www.rsp.fsp.usp.br/
Revista de Saúde Pública

\title{
Quality of cervical cancer screening in Brazil: external assessment of the PMAQ
}

\author{
Mara Rejane Barroso Barcelos', Rita de Cássia Duarte Lima", Elaine Tomasi"II, Bruno Pereira Nunes ${ }^{\text {IV }}$, \\ Suele Manjourany Silva Duro" ${ }^{\text {, }}$ Luiz Augusto Facchini"II \\ I Departamento de Ginecologia e Obstetrícia. Centro de Ciências da Saúde. Universidade Federal do Espírito Santo. \\ Vitória, ES, Brasil \\ " Departamento de Enfermagem. Centro de Ciências da Saúde. Universidade Federal do Espírito Santo. \\ Vitória, ES, Brasil \\ III Departamento de Medicina Social. Faculdade de Medicina. Universidade Federal de Pelotas. Pelotas, RS, Brasil \\ Iv Departamento de Enfermagem. Faculdade de Enfermagem. Universidade Federal de Pelotas. Pelotas, RS, Brasil
}

\section{ABSTRACT}

OBJECTIVE: To examine whether demographic and socioeconomic variables and the variables of the organization of services are associated with the quality of cervical cancer screening.

METHODS: This is a survey carried out in the health services of the five Brazilian regions in 2012. The sample consisted of users of basic health units participating in the Program for Improving Access and Quality of the Primary Care. The independent variables analyzed were: socioeconomic characteristics (municipal context), demographic characteristics (user profile), and two domains related to the organization of basic services (work structure and process). The low quality of the screening was assessed from the lack of access, late examination, and lack of guidance. Crude and adjusted analyses by Poisson regression assessed the association between outcomes and independent variables.

RESULTS: The values of lack of access, late examination, and lack of guidance were $6.7 \%, 11.2 \%$, and $19.2 \%$, respectively. Problems of quality were lower according to the increase in Municipal Human Development Index and per capita household income, increasing with population size and municipal coverage of the Family Health Strategy. The Midwest region of the country presented the highest occurrences of low quality outcomes. Indigenous and yellow women had the highest prevalence of outcomes. Women with partner, who received the Bolsa Familia Program, and who had paid work had less chances of having lack of access, late examination, and lack of guidance. The appropriate work process in health services decreased the likelihood of low quality in all indicators.

CONCLUSIONS: Investments in the work process of health teams, social cash transfer programs, and social conditions of the population are essential to improve the quality of the program of cervical cancer screening in Brazil.

DESCRIPTORS: Uterine Cervical Neoplasms, diagnosis. Socioeconomic Factors. Women's Health Services. Program Evaluation. 


\section{INTRODUCTION}

Cervical cancer is an important public health problem, being the third most frequent and the fourth cause of mortality in women in Brazil, with an annual incidence of 16,340 cases, estimated risk of 15.85 cases per 100,000 women, and mortality rate of 4.86 cases per 100,000 women'.

According to the parameters of the World Health Organization (WHO), the estimated incidence of this cancer should be up to 16.3 cases per 100,000 women and, for mortality, 7.3 per 100,000 women. The challenge of Brazil is to reduce them further, using as references Western Asia, with incidence of 4.4 cases per 100,000 women, as well as Australia and New Zealand, with incidences of 5.5 cases per 100,000 women, which, along with Western Europe, have death rates of less than two per 100,000 women ${ }^{28}$.

In this context, care actions become relevant for women's health and cervical cancer screening, priorities for the Brazilian Unified Health System (SUS) and the Brazilian research agenda ${ }^{a}$. After the implementation of population-based screening programs in developed countries, there was a reduction in mortality from cervical cancer ${ }^{26,28}$.

For the screening of the problem, the WHO recommends that at least $80 \%$ of the women aged between 25 and 64 years, who have already begun sexual activity, perform the cervical Pap smear test every three years, after two consecutive annual negative controls ${ }^{27}$. In Brazil, the Plano de Enfrentamento de Doenças Crônicas 2011-2022 (2011-2022 Plan for Combating Chronic Diseases) ${ }^{17}$ set a goal of $85 \%$ for the coverage of the exam. Screening in this age group is justified by the increased occurrence of high grade lesions, which can have effective treatment, preventing its evolution into cancer 9 . Among the criteria for the screening test, we can mention security, easy acceptance, proven sensitivity and specificity, and good cost-effectiveness ${ }^{9}$, which are found in the Pap smear test.

Coinciding with the implementation and consolidation of the SUS and the Family Health Strategy (FHS), Brazilian estimates show that the coverage of the Pap smear increased from $82.6 \%$ in 2003 to $87.6 \%$ in $2008^{7}$, achieving international and national goals ${ }^{15,26,27}$. Despite the contributions of the primary health care in the expansion of the coverage and offer of cervical cancer screening and control in Brazil ${ }^{4}$, several studies have observed smaller coverage among women with higher social vulnerability, especially in the poorest regions of the country ${ }^{11,16}$. The social inequities observed suggest the need for a better understanding of the reasons underlying the high incidence and mortality rates from cervical cancer in relation to the high provision and coverage of a procedure for potentially effective early diagnosis. Problems in the quality of collection procedures, the agility of results, and the timely treatment of lesions ${ }^{17}$, often arising from shortcomings in the work structure and process of primary care services ${ }^{24}$, may negatively reflect on the occurrence of cervical cancer, requiring further deepening with comprehensive studies.

In this sense, we intended to address the quality of cervical cancer screening of the basic health network across Brazil, using data from the Programa de Melhoria do Acesso e da Qualidade da Atenção Básica (PMAQ - Program for Improving Access and Quality of the Primary Care). This program encourages the improvement of access and quality practices and consists of the stages of adherence, contracting, development, external assessment, and recontracting ${ }^{b}$. This study is part of the external assessment of the PMAQ, with particular emphasis on the services of the FHS .

Seeking to better understand the problem and support the effectiveness of the primary health care, this study analyzes the relationship between the socioeconomic (municipal context) and demographic (user profile) variables, two domains related to the organization of basic services (work structure and process), and three outcomes selected to assess the quality of the cervical cancer screening in users of Basic Health Units (BHU) participating in the PMAQ. 


\section{METHODS}

This is a survey on health services, being the first cycle of the external assessment of the PMAQ. The scenario in this study was the BHU, with voluntary adherence of the teams to the program. We assessed, using a census of the structure of services, 38,812 BHU, located in all Brazilian municipalities. Additionally, we studied the work process of 17,202 primary health care teams, located in 3,965 municipalities ( $71.3 \%$ of the total) that joined the PMAQ, and we interviewed 65,391 individuals (approximately four users per team). For this study, we selected 35,844 users within the teams assessed, which represented the total of women participating in the study aged between 25 and 64 who used the health services, regardless of reason. In each team, a health professional with higher education provided information about the characteristics of the work structure and process of the service. The 17,202 teams assessed were located in 13,843 BHU, selected for this study. We did not include the remaining $24,969 \mathrm{BHU}$ for which information was available only on the structure of services.

Data collection occurred between June 2012 and March 2013 from the application of electronic questionnaires, available in tablets, by approximately 1,000 interviewers and supervisors selected after qualification. The tablets were essential to give agility to the process and ensure the quality of the research data. The quality control strategy involved the supervision of the data collection process, the use of an electronic validator, the checking of the consistency of each question, the checking of the consistency between answers, and the control of the time of the interview by comparing their start and end times.

To meet the objectives of this article, we estimated sample size considering the following parameters: a significance level of $5 \%, 80 \%$ power, rate of those not exposed to those exposed of 1:6, and prevalence of outcome of $55 \%$ among those not exposed. To detect prevalence ratios starting from 1.1, we estimated a sample of 5,325 women. By adding $10 \%$ for losses and refusals and $15 \%$ for the control of confounding factors, the sample size required was 6,735 women.

The survey instrument was comprised of three modules: Module I - health unit observation; Module II - interview with the primary care professional team and verification of documents in the health unit; and, Module III - interview with users in the health unit.

In Module I, the structure of the BHU was characterized by direct observation of the interviewers. In Module II, we assessed the work process of the team, interviewing a professional with higher education from each health team. In Module III, we interviewed the users who were at the BHU on the day of the external assessment and who had used the services of the unit at least once in the year prior to the interview.

The outcomes of this study measured problems in the quality of cervical cancer screening, from three indicators: proportion of women aged 25 to 64 years interviewed at the BHU who had never performed the examination (lack of access throughout life), cervical cancer screening that was performed more than 36 months ago (late examination), and no guidance on the importance of the preventive examination for cervical cancer and the period for new collection (lack of guidance).

The independent variables included the characteristics of the social context, the individuals, and the work structure and process of the BHU. For context, we selected the Municipal Human Development Index (MHDI) with distribution according to quartiles (up to 0.658, 0.659 to $0.750,0.751$ to $0.806,0.807$ to 0.819 ), population size of the municipalities (up to 30,000 , 30,001 to $100,000,100,001$ to 500,000, over 500,000 inhabitants), FHS coverage (up 29.9\%, 30\% to $64.9 \%, 65 \%$ or over), and geographic region (North, Northeast, Midwest, Southeast, South). The MHDI is a marker of wealth of municipalities, consisting of data on life expectancy at birth, education, and per capita Gross Domestic Product (GDP), ranging from zero (no human development) to one (total human development), categorized into quartiles ${ }^{7}$.

Population size of the municipality can be considered a marker of the conditions of wealth and infrastructure available ${ }^{5}$. The FHS coverage is taken in this study as a proxy of the governance 
decision in favor of extending basic health services capable of promoting greater equity in care, favoring vulnerable territories and populations ${ }^{5}$.

Individual variables were: age in full years ( 25 to 35,36 to 49,50 to 64 ), self-reported race according to the categories of the Brazilian Institute of Geography and Statistics (IBGE) (white, black, brown, yellow, indigenous), marital status (no partner; with partner), number of residents (1 to 3, 4 to 5, 6 or more), being part of the Bolsa Familia Program (no, yes), paid work (no, yes), and per capita family income in quartiles (up to $\mathrm{R} \$ 104, \mathrm{R} \$ 105$ to $\mathrm{R} \$ 188, \mathrm{R} \$ 189$ to $\mathrm{R} \$ 300, \mathrm{R} \$ 301$ or over). The number of residents in the household, being part of the Bolsa Familia Program, and the per capita family income are markers of the social condition of users.

In relation to the structure for the development of screening actions, we considered as appropriate the availability of all ten inputs and materials: gynecological examination table, spotlight, gloves, disposable speculum, endocervical brush, Ayre spatula, slide clamp, glass slide, plastic jar with lid, and request record of the Sistema de Informações do Câncer do Colo do Útero (SISCOLO - Information System of Cervical Cancer). The presence of seven to nine inputs was classified as less adequate, and the availability of six or fewer inputs was classified as inadequate. As for the work process, we considered as adequate the reference of all six actions of the team: collection of cervical cytology, record of women with late Pap smear, record of altered Pap smear, follow-up of women after treatment, use of dissemination and awareness strategies for examination, and provision of educational and health promotion actions focused on cervical cancer. The mention of four to five actions was classified as less adequate, and three or fewer actions were classified as inadequate.

Stata 13,0 (College Station, TX) was used for all data analysis. We carried out the description of the frequency distribution and the bivariate analysis between the outcomes and the contextual and individual variables and the variables of the characteristics of health services using the Chi-square test for heterogeneity (nominal categorical and dichotomous variables) and linear trend (ordinal categorical variables). For the crude and adjusted analyses, we use Poisson regression with robust variance according to the independent variables, and the statistical significance was obtained using Wald test for heterogeneity and linear trend, according to the type of each variable. In the adjusted analysis, we adopted a hierarchical model consisting of three levels: distal, with the characteristics of the social context (MHDI, population size, FHS coverage, and geographic region); intermediate, grouping the demographic and socioeconomic characteristics of users (age, race, marital status, number of residents, Bolsa Familia benefit, paid work, and per capita income); and, proximal, with the aspects of health services (structure and team work process) directly involved with the performance of cervical cancer screening. In each of the hierarchical levels, we carried out the backward regression and we kept all the variables with $p$-value $\leq 0.20$ in the model. For all analyses, we considered a significance level of $5 \%$.

The project of external assessment of the PMAQ was submitted to the Research Ethics Committee of the Universidade Federal de Pelotas (Number 38/2012, May 10, 2012). An informed consent was obtained from all users interviewed.

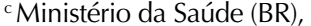
Secretaria de Atenção à Saúde, Departamento de Atenção Básica. Controle dos cânceres do colo do útero e da mama. 2.ed. Brasília (DF): Ministério da Saúde; 2013 [cited 2016 Feb 27]. (Cadernos de Atenção Básica, 13). Available from: http://dab. saude.gov.br/portaldab/biblioteca. php? conteudo=publicacoes/cab13

\section{RESULTS}

The total of 35,844 users aged 25 to 64 years was located at 17,202 health teams that were installed in 13,843 BHU. Of the total of BHU studied, $62.3 \%$ had only one health team. According to Table 1, compliance to the study showed difference between regions, being higher in the Southeast (37.1\%) and lower in the North (5.6\%). Loss of information was small for the variables under study, except for per capita income. The missing data for the variables of MHDI, population size, FHS coverage, and geographic region was $2 \%$ of the total. The variables of age, marital status, Bolsa Familia, and paid work showed no missing data (0\%). The variable of race had missing data of $0.8 \%$; the number of residents, $0.3 \%$; and, per capita income, $16.7 \%$. The variable of adequacy of the structure had missing data of $2.3 \%$ and adequacy of the process, $3.4 \%$. 
Approximately $50.0 \%$ of the interviewees lived in municipalities with MHDI of up to $0.75,63.2 \%$ lived in small and medium-sized municipalities (with up to 100,000 inhabitants), 58.6\% lived in municipalities with over $65.0 \%$ of FHS coverage, and $73.8 \%$ lived in the Northeastern and Southeastern States. Regarding the demographic and socioeconomic characteristics, most were aged between 25 and 35 years (37.4\%), were brown (47.3\%), lived with partner (75.2\%), lived in households with up to three persons (43.0\%), did not receive Bolsa Familia (52.9\%), had no paid work (67.3\%), and had per capita income greater than $\mathrm{R} \$ 189,00(60.2 \%)$. In relation to the characteristics of the health unit, $37.1 \%$ and $33.3 \%$ of the women were interviewed in units with adequate structure and process for examination, respectively (Table 1).

When we individually look at the materials and inputs that made up the variable of adequate structure, we identified that $94.6 \%$ of the women were interviewed at a BHU that had gynecological exam table, $95.3 \%$ had spotlight for gynecological examination, 94.0\% had brush for the collection of Pap smear, $85.2 \%$ had disposable speculum, $94.2 \%$ had Ayre spatula, $80.0 \%$ had slide clamp, $70.3 \%$ had plastic bottle with lid, $93.5 \%$ had frosted glass slide, $74.4 \%$ had gloves, and $92.2 \%$ had record to request Pap smear. Regarding the work procedure of the teams of the BHU, $97.4 \%$ of the women were present in services that collected Pap smear, $82.6 \%$ had the record with the number of women with altered examination, $87.7 \%$ carried out the follow-up of women after treatment, $92.4 \%$ used dissemination and awareness strategies for Pap smear, $82.6 \%$ provided educational and health promotion actions focused on cervical cancer, and $44.2 \%$ had the record of the number of women with late collection.

Of the total number of users studied, 28,279 (79.4\%) reported having had Pap smear at the BHU where they were interviewed, and 4,970 (14.0\%) reported not performing it at that BHU. Of the latter ones, 1,557 (31.3\%) had the test at another BHU, 527 (10.6\%) reported doing so in a hospital, 1,672 (33.6\%) in private practice, and 315 (6.3\%) in another location.

In addition, 2,368 women reported never having carried out cervical cancer screening, resulting in a prevalence of lack of access throughout life of 6.7\% (95\%CI 6.4-6.9). Among those interviewed, the frequency of late examinations (over 36 months) was 11.2\% (95\%CI 10.8-11.5), and the lack of guidance was reported by $19.2 \%$ of the women (95\%CI 18.7-19.6) (Figure).

In the bivariate analysis, the outcomes of lack of access throughout life, last exam being over 36 months ago, and lack of guidance on the examination showed linear increase trend, as the HDI of the municipalities decreased (Table 1). In the adjusted analysis (Table 2), lack of access throughout life, late examination, and the lack of guidance were 2.42, 1.85, and 1.35 times higher, respectively, in poorer municipalities (MHDI up to 0.658) compared to richer municipalities (MHDI above 0.806).

With the increase in the population size of the municipality there was also a decrease in the proportion of lack of access throughout life and examination carried out more than 36 months ago, but there was an increase in the lack of guidance on the examination (Table 1). However, in the adjusted analysis, we observed a change in the pattern identified, with a significant increase of the three outcomes with the increase in population size (Table 2).

Regarding the Family Health coverage in the municipality, the lack of access throughout life and examination carried out more than 36 months ago was greater in the municipalities with greater coverage; on the other hand, lack of guidance had no significant difference (Table 1). When performing the adjusted analysis, lack of access throughout life did not keep the association with FHS coverage, late examination kept the pattern of the gross analysis, and lack of guidance on the examination showed an increase of $18 \%$ in the stratum of greater coverage (Table 2).

The South and Southeast regions showed improved performance for the quality indicators of cervical cancer screening compared to the Midwest, Northeast, and North regions (Table 1). In the adjusted analysis, the lack of access throughout life and late examination 
Table 1. Description of the sample and bivariate analyses between outcomes and contextual and individual variables and the variables of characteristics of health services. PMAQ, Brazil, 2012.

\begin{tabular}{|c|c|c|c|c|c|c|c|c|}
\hline \multirow[t]{2}{*}{ Variable } & \multicolumn{2}{|c|}{$\begin{array}{l}\text { Distribution of } \\
\text { the sample }\end{array}$} & \multicolumn{2}{|c|}{$\begin{array}{l}\text { Lack of access } \\
\text { throughout life }\end{array}$} & \multicolumn{2}{|c|}{$\begin{array}{l}\text { Examination carried out } \\
\text { more than } 36 \text { months ago }\end{array}$} & \multicolumn{2}{|c|}{$\begin{array}{l}\text { No guidance on } \\
\text { the examination }\end{array}$} \\
\hline & $\mathbf{n}$ & $\%$ & $\%(95 \% \mathrm{Cl})$ & $\mathbf{p}$ & $\%(95 \% \mathrm{Cl})$ & $\mathbf{p}$ & $\%(95 \% \mathrm{Cl})$ & $\mathbf{p}$ \\
\hline MHDI & & & & $<0.001^{*}$ & & $<0.001^{*}$ & & $0.001^{*}$ \\
\hline Up to 0.658 & 8,867 & 25.2 & $8.7(8.1-9.3)$ & & $13.2(12.5-13.9)$ & & $19.2(18.4-20.1)$ & \\
\hline 0.659 to 0.75 & 8,813 & 25.1 & $7.0(6.4-7.6)$ & & $11.3(10.6-12.0)$ & & $19.8(18.9-20.6)$ & \\
\hline 0.751 to 0.806 & 8,713 & 24.8 & $5.8(5.3-6.3)$ & & $10.6(9.9-11.2)$ & & $19.3(18.5-20.1)$ & \\
\hline 0.807 to 0.919 & 8,738 & 24.9 & $4.7(4.3-5.2)$ & & $9.3(8.6-9.9)$ & & $17.8(17.0-18.6)$ & \\
\hline Population size (inhabitants) & & & & $<0.001^{*}$ & & $0.001 *$ & & $<0.001^{*}$ \\
\hline Up to 30,000 & 14,744 & 42.0 & $7.3(6.8-7.7)$ & & $11.6(11.0-12.1)$ & & $17.9(17.3-18.6)$ & \\
\hline 30,001 up to 100,000 & 7,445 & 21.2 & $6.8(6.2-7.4)$ & & $11.5(10.8-12.3)$ & & $19.1(18.2-20.0)$ & \\
\hline 100,001 up to 500,000 & 6,422 & 18.3 & $5.6(5.1-6.2)$ & & $10.4(9.6-11.1)$ & & $20.1(19.2-21.3)$ & \\
\hline 500,001 or more & 6,520 & 18.6 & $5.7(5.1-6.3)$ & & $10.2(9.5-11.0)$ & & $20.3(19.3-21.3)$ & \\
\hline FHS coverage $(\%)$ & & & & $<0.001^{*}$ & & $<0.001^{*}$ & & 0.080 \\
\hline Up to 29.9 & 2,858 & 8.1 & $5.5(4.7-6.3)$ & & $9.4(8.3-10.5)$ & & $18.8(17.3-20.2)$ & \\
\hline 30 to 64.9 & 11,696 & 33.3 & $5.6(5.2-6.1)$ & & $10.2(9.6-10.7)$ & & $18.5(17.8-19.2)$ & \\
\hline 65 or more & 20,577 & 58.6 & $7.3(6.9-7.6)$ & & $11.9(11.4-12.3)$ & & $19.4(18.8-19.9)$ & \\
\hline Geographic region & & & & $<0.001$ & & $<0.001$ & & $<0.001$ \\
\hline North & 1,955 & 5.6 & $7.8(6.6-9.0)$ & & $11.5(10.1-13.0)$ & & $22.4(20.5-24.3)$ & \\
\hline Northeast & 12,897 & 36.7 & $7.7(7.2-8.1)$ & & $12.0(11.5-12.6)$ & & $19.6(18.9-20.3)$ & \\
\hline Southeast & 13,026 & 37.1 & $5.8(5.4-6.2)$ & & $10.4(9.9-11.0)$ & & $18.3(17.6-19.0)$ & \\
\hline South & 5,178 & 14.7 & $4.6(4.1-5.2)$ & & $9.2(8.4-10.0)$ & & $16.1(15.1-17.2)$ & \\
\hline Midwest & 2,075 & 5.9 & $8.6(7.4-9.8)$ & & $13.7(12.1-15.2)$ & & 23.7 (21.9-25.6) & \\
\hline Age (years) & & & & $<0.001^{*}$ & & $0.001^{*}$ & & $<0.001^{*}$ \\
\hline 25-35 & 13,397 & 37.4 & $8.3(7.8-8.8)$ & & $12.1(11.6-12.7)$ & & $20.6(19.9-21.3)$ & \\
\hline $35-49$ & 11,846 & 33.1 & $4.8(4.4-5.2)$ & & $9.1(8.6-9.6)$ & & $16.6(15.9-17.2)$ & \\
\hline $50-64$ & 10,601 & 29.6 & $6.6(6.1-7.1)$ & & $12.3(11.7-12.9)$ & & $20.2(19.4-21.0)$ & \\
\hline Race & & & & $<0.001$ & & $<0.001$ & & $<0.001$ \\
\hline White & 13,197 & 37.1 & $5.6(5.2-6.0)$ & & $10.0(9.5-10-6)$ & & $17.8(17.2-18.5)$ & \\
\hline Black & 4,223 & 11.9 & $7.5(6.7-8.3)$ & & $12.0(11.0-13.0)$ & & $20.4(19.2-21.6)$ & \\
\hline Yellow & 996 & 2.8 & $8.6(6.9-10.3)$ & & $12.9(10.8-15.1)$ & & $23.4(20.7-26.0)$ & \\
\hline Brown & 16,841 & 47.3 & $7.0(6.7-7.4)$ & & $11.6(11.1-12.1)$ & & $19.4(18.8-20.0)$ & \\
\hline Indigenous & 315 & 0.9 & $9.7(6.3-12.9)$ & & $15.8(11.6-19.9)$ & & $26.6(21.6-31.6)$ & \\
\hline Marital status & & & & $<0.001$ & & $<0.001$ & & $<0.001$ \\
\hline Without partner & 8,881 & 24.8 & $9.3(8.7-9.9)$ & & $15.0(14.2-15.7)$ & & $22.7(21.8-23.6)$ & \\
\hline With partner & 26,963 & 75.2 & $5.8(5.5-6.1)$ & & $10.0(9.6-10.6)$ & & $18.0(17.5-18.5)$ & \\
\hline Number of residents & & & & $<0.001^{*}$ & & $0.001^{*}$ & & $<0.001^{*}$ \\
\hline $1-3$ & 15,389 & 43.0 & $7.0(6.6-7.4)$ & & $11.5(11.0-12.0)$ & & $20.0(19.4-20.6)$ & \\
\hline $4-5$ & 15,147 & 42.4 & $5.8(5.4-6.1)$ & & $9.9(9.4-10.4)$ & & $18.0(17.4-18.6)$ & \\
\hline 6 or more & 5,216 & 14.6 & $8.1(7.4-8.9)$ & & $13.8(12.8-14.7)$ & & $19.9(18.8-21.0)$ & \\
\hline Bolsa Família Program & & & & 0.36 & & 0.06 & & 0.004 \\
\hline No & 18,974 & 52.9 & $6.5(6.2-6.9)$ & & $10.9(10.4-11.3)$ & & $19.7(19.1-20.3)$ & \\
\hline Yes & 16,870 & 47.1 & $6.8(6.4-7.2)$ & & $11.5(11.0-12.0)$ & & $18.5(17.9-19.1)$ & \\
\hline Paid work & & & & $<0.001$ & & $<0.001$ & & $<0.001$ \\
\hline No & 24,104 & 67.3 & $7.1(6.8-7.4)$ & & $12.0(11.6-12.4)$ & & $19.9(19.4-20.4)$ & \\
\hline Yes & 11,740 & 32.8 & $5.7(5.3-6.1)$ & & $9.5(8.9-10.0)$ & & $17.7(17.0-19.0)$ & \\
\hline Income per capita (in quartiles) & & & & $<0.001^{*}$ & & $<0.001^{*}$ & & $<0.001^{*}$ \\
\hline Up to 104 & 6,160 & 20.6 & $8.7(8.0-9.4)$ & & $14.0(13.1-14.9)$ & & $20.3(19.3-21.3)$ & \\
\hline 105 to 188 & 5,737 & 19.2 & $6.4(5.8-7.1)$ & & $10.8(10.0-11.7)$ & & $18.0(17.0-19.0)$ & \\
\hline 189 to 300 & 6,561 & 22.0 & $6.0(5.4-6.5)$ & & $10.8(10.0-11.5)$ & & $18.7(17.7-19.6)$ & \\
\hline 301 or more & 11,395 & 38.2 & $5.6(5.2-6.1)$ & & $9.8(9.2-10.3)$ & & $18.8(18.0-19.5)$ & \\
\hline Adequacy of the structure & & & & $<0.001$ & & $<0.001$ & & $<0.001$ \\
\hline Inadequate & 2,320 & 6.6 & $8.9(7.8-10.1)$ & & $13.6(12.2-15.1)$ & & $22.8(21.1-24.5)$ & \\
\hline Less adequate & 19,727 & 56.3 & $6.8(6.4-7.2)$ & & $11.4(11.0-11.9)$ & & $19.9(19.3-20.4)$ & \\
\hline Adequate & 12,975 & 37.1 & $5.8(5.4-6.2)$ & & $10.1(9.6-10.6)$ & & $17.0(16.3-17.6)$ & \\
\hline Adequacy of the process & & & & $<0.001$ & & $<0.001$ & & $<0.001$ \\
\hline Inadequate & 3,867 & 11.2 & $8.1(7.3-9.0)$ & & $13.2(12.1-14.3)$ & & $24.0(22.6-25.3)$ & \\
\hline Less adequate & 19,211 & 55.5 & $6.7(6.3-7.0)$ & & $11.4(10.9-11.8)$ & & $19.8(19.2-20.4)$ & \\
\hline Adequate & 11,537 & 33.3 & $5.8(5.4-6.3)$ & & $9.9(9.3-10.4)$ & & $15.8(15.1-16.5)$ & \\
\hline
\end{tabular}

PMAQ: Program for Improving Access and Quality of the Primary Care; MHDI: Municipal Human Development Index; FHS: Family Health Strategy

* p-value: Chi-square test for linear trend. 


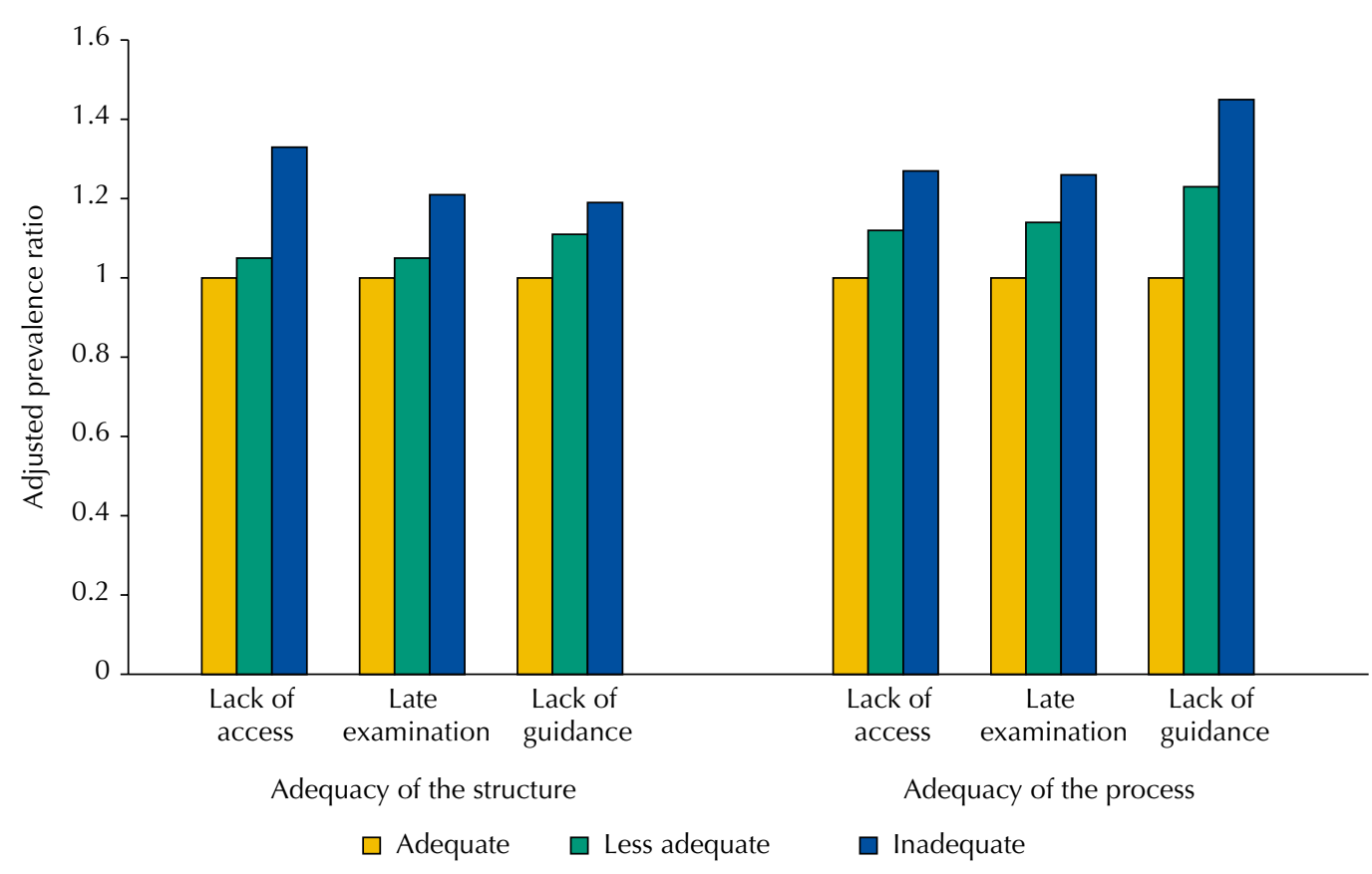

Figure. Quality of the adequacy of the work structure and process in the units of the Family Health Strategy. PMAQ, Brazil, 2012.

were significantly higher in the Midwest region, which also showed a greater probability of lack of guidance on the examination, together with the North region, when compared to the other regions (Table 2).

The proportions of lack of access throughout life, examination carried out over 36 months ago, and lack of guidance on the examination were significantly lower in users aged 35 to 49 years, when compared to those aged 25 to 35 years and 50 to 64 years (Table 1). This pattern remained unchanged in the adjusted analysis, with the worst quality indicators of cervical cancer screening among younger women (25-35 years) (Table 2).

White users had the lowest prevalence of lack of access throughout life, examination carried out more than 36 months ago, and lack of guidance on the examination, in contrast with self-reported indigenous or yellow users, who presented the worst situation for the three indicators, and brown and black women were in an intermediate position (Table 1). This pattern was kept in the adjusted analysis (Table 2).

Users with no partner, no paid work, and with lower per capita household income presented the worst prevalence for the three outcomes (Table 1). In the adjusted analysis, this pattern was kept in relation to marital status and paid work. In relation to per capita income, the association was no longer significant for lack of guidance on the examination (Table 2). Users living in households with four to five residents had lower prevalence for the three outcomes in both the crude and adjusted analyzes.

In relation to Bolsa Familia, the lack of access throughout life was not associated in the crude analysis, but it became significantly greater in the adjusted analysis among users who did not receive the benefit. Late examination did not show an association with Bolsa Familia either in the crude or in the adjusted analysis. On the other hand, lack of guidance on the examination was significantly higher in users who did not receive the benefit, both for the crude and adjusted analyses.

Lower prevalence for the three quality outcomes of cervical cancer screening was also present among users of services with adequate work structure and process for examination (Tables 1 and 2). 
Table 2. Crude and adjusted analysis between outcomes and contextual and individual variables and the variables of characteristics of health services. PMAQ, Brazil, 2012.

\begin{tabular}{|c|c|c|c|c|c|c|}
\hline \multirow{3}{*}{ Variable } & \multicolumn{2}{|c|}{$\begin{array}{l}\text { Lack of access } \\
\text { throughout life }\end{array}$} & \multicolumn{2}{|c|}{$\begin{array}{c}\text { Examination carried out more } \\
\text { than } 36 \text { months ago }\end{array}$} & \multicolumn{2}{|c|}{$\begin{array}{l}\text { No guidance on } \\
\text { the examination }\end{array}$} \\
\hline & Crude analysis & Adjusted analysis & Crude analysis & Adjusted analysis & Crude analysis & Adjusted analysis \\
\hline & PR $(95 \% \mathrm{Cl})$ & PR $(95 \% \mathrm{Cl})$ & PR $(95 \% \mathrm{Cl})$ & PR $(95 \% \mathrm{Cl})$ & PR $(95 \% \mathrm{Cl})$ & PR $(95 \% \mathrm{Cl})$ \\
\hline MHDI & $p<0.001^{*}$ & $\mathrm{p}<0.001^{*}$ & $\mathrm{p}<0.001^{*}$ & $p<0.001^{*}$ & $p=0.009^{*}$ & $p<0.001^{*}$ \\
\hline Up to 0.658 & $1.84(1.64-2.07)$ & $2.42(1.89-3.09)$ & $1.43(1.31-1.56)$ & $1.85(1.54-2.22)$ & $1.08(1.02-1.15)$ & $1.35(1.18-1.54)$ \\
\hline 0.659 to 0.75 & $1.49(1.32-1.68)$ & $1.73(1.43-2.11)$ & $1.22(1.11-1.33)$ & $1.40(1.21-1.62)$ & $1.11(1.05-1.19)$ & $1.25(1.12-1.38)$ \\
\hline 0.751 to 0.806 & $1.23(1.08-1.39)$ & $1.39(1.19-1.62)$ & $1.14(1.04-1.25)$ & $1.27(1.13-1.42)$ & $1.09(1.02-1.16)$ & $1.20(1.11-1.30)$ \\
\hline 0.807 to 0.919 & 1.00 & 1.00 & 1.00 & 1.00 & 1.00 & 1.00 \\
\hline Population size (inhabitants) & $\mathrm{p}<0.001^{*}$ & $p=0.002^{*}$ & $p=0.001^{*}$ & $\mathrm{p}<0.001^{*}$ & $\mathrm{p}<0.001^{*}$ & $\mathrm{p}<0.001^{*}$ \\
\hline Up to 30,000 & 1.00 & 1.00 & 1.00 & 1.00 & 1.00 & 1.00 \\
\hline 30,001 up to 100,000 & $0.93(0.84-1.03)$ & $1.07(0.96-1.20)$ & $1.00(0.92-1.08)$ & $1.12(1.03-1.22)$ & $1.07(1.01-1.13)$ & $1.14(1.07-1.22)$ \\
\hline 100,001 up to 500,000 & $0.78(0.69-0.87)$ & $1.14(0.98-1.33)$ & $0.90(0.82-0.98)$ & $1.21(1.08-1.36)$ & $1.12(1.06-1.19)$ & $1.35(1.25-1.47)$ \\
\hline 500,001 or more & $0.78(0.70-0.88)$ & $1.42(1.17-1.73)$ & $0.88(0.81-0.97)$ & $1.33(1.15-1.54)$ & $1.13(1.06-1.20)$ & $1.49(1.35-1.65)$ \\
\hline FHS coverage $(\%)$ & $\mathrm{p}<0.001^{*}$ & $p=0.084$ & $\mathrm{p}<0.001^{*}$ & $p=0.001^{*}$ & $p=0.085$ & $\mathrm{p}<0.001^{*}$ \\
\hline Up to 29.9 & 1.00 & 1.00 & 1.00 & 1.00 & 1.00 & 1.00 \\
\hline 30.0 to 64.9 & $1.03(0.87-1.22)$ & $1.04(0.88-1.24)$ & $1.08(0.95-1.23)$ & $1.10(0.97-1.26)$ & $0.98(0.90-1.07)$ & $1.01(0.92-1.10)$ \\
\hline 65,0 or more & $1.32(1.13-1.55)$ & $1.17(0.98-1.41)$ & $1.26(1.11-1.42)$ & $1.24(1.08-1.43)$ & $1.03(0.95-1.12)$ & $1.18(1.07-1.29)$ \\
\hline Geographic region & $p<0.001$ & $p<0.001$ & $p<0.001$ & $p<0.001$ & $p<0.001$ & $p<0.001$ \\
\hline Midwest & $1.86(1.54-2.24)$ & $1.58(1.30-1.91)$ & $1.49(1.29-1.71)$ & $1.34(1.16-1.55)$ & $1.47(1.33-1.63)$ & $1.37(1.24-1.52)$ \\
\hline North & $1.69(1.39-2.53)$ & $1.21(0.97-1.51)$ & $1.26(1.08-1.46)$ & $1.01(0.85-1.20)$ & $1.39(1.25-1.54)$ & $1.22(1.08-1.37)$ \\
\hline Northeast & $1.66(1.44-1.90)$ & $0.97(0.81-1.17)$ & $1.31(1.19-1.45)$ & $0.90(0.78-1.03)$ & $1.22(1.13-1.31)$ & $1.01(0.91-1.12)$ \\
\hline Southeast & $1.25(1.08-1.44)$ & $1.13(0.97-1.30)$ & $1.14(1.03-1.26)$ & $1.06(0.95-1.18)$ & $1.14(1.06-1.22)$ & $1.05(0.97-1.13)$ \\
\hline South & 1.00 & 1.00 & 1.00 & 1.00 & 1.00 & 1.00 \\
\hline Age (years) & $p<0.001$ & $p<0.001$ & $p<0.001$ & $p<0.001$ & $p<0.001$ & $p<0.001$ \\
\hline 25-35 & $1.74(1.57-1.92)$ & $1.74(1.55-1.95)$ & $1.33(1.24-1.44)$ & $1.32(1.21-1.44)$ & $1.24(1.18-1.31)$ & $1.25(1.19-1.32)$ \\
\hline $35-49$ & 1.00 & 1.00 & 1.00 & 1.00 & 1.00 & 1.00 \\
\hline 50-64 & $1.38(1.24-1.54)$ & $1.22(1.07-1.39)$ & $1.35(1.25-1.46)$ & $1.22(1.12-1.34)$ & $1.22(1.15-1.29)$ & $1.12(1.06-1.19)$ \\
\hline Race & $p<0.001$ & $p=0.002$ & $\mathrm{p}<0.001$ & $p=0.008$ & $\mathrm{p}<0.001$ & $p<0.001$ \\
\hline White & 1.00 & 1.00 & 1.00 & 1.00 & 1.00 & 1.00 \\
\hline Brown & $1.26(1.15-1.38)$ & $1.11(1.00-1.24)$ & $1.16(1.08-1.24)$ & $1.08(1.00-1.17)$ & $1.09(1.04-1.14)$ & $1.02(0.97-1.08)$ \\
\hline Black & $1.34(1.18-1.52)$ & $1.24(1.07-1.44)$ & $1.20(1.09-1.32)$ & $1.12(1.00-1.26)$ & $1.14(1.07-1.23)$ & $1.09(1.02-1.18)$ \\
\hline Yellow & $1.54(1.24-1.91)$ & $1.43(1.13-1.82)$ & $1.29(1.08-1.53)$ & $1.30(1.07-1.57)$ & $1.31(1.16-1.48)$ & $1.24(1.10-1.40)$ \\
\hline Indigenous & $1.72(1.22-2.44)$ & $1.48(1.01-2.18)$ & $1.57(1.20-2.05)$ & $1.44(1.07-1.93)$ & $1.49(1.23-1.80)$ & $1.33(1.09-1.63)$ \\
\hline Marital status & $p<0.001$ & $p<0.001$ & $p<0.001$ & $p<0.001$ & $\mathrm{p}<0.001$ & $p<0.001$ \\
\hline Without partner & $1.61(1.49-1.75)$ & $1.63(1.48-1.80)$ & $1.51(1.41-1.60)$ & $1.50(1.39-1.61)$ & $1.26(1.20-1.32)$ & $1.24(1.18-1.30)$ \\
\hline With partner & 1.00 & 1.00 & 1.00 & 1.00 & 1.00 & 1.00 \\
\hline Number of residents & $p<0.001$ & $p=0.015$ & $\mathrm{p}<0.001$ & $\mathrm{p}<0.001$ & $p<0.001$ & $p=0.016$ \\
\hline $1-3$ & 1.00 & 1.00 & 1.00 & 1.00 & 1.00 & 1.00 \\
\hline $4-5$ & $0.83(0.76-0.90)$ & $0.87(0.78-0.96)$ & $0.86(0.81-0.92)$ & $0.92(0.84-0.99)$ & $0.90(0.86-0.94)$ & $0.94(0.88-0.99)$ \\
\hline 6 or more & $1.16(1.04-1.29)$ & $1.01(0.88-1.16)$ & $1.20(1.10-1.30)$ & $1.13(1.02-1.26)$ & $0.99(0.93-1.06)$ & $0.95(0.88-1.03)$ \\
\hline Bolsa Família Program & $p=0.361$ & $p<0.001$ & $p=0.056$ & $p=0.187$ & $p=0.004$ & $p<0.001$ \\
\hline No & $0.96(0.89-1.04)$ & $1.26(1.13-1.40)$ & $0.94(0.89-1.00)$ & $1.06(0.97-1.15)$ & $1.07(1.02-1.11)$ & $1.13(1.07-1.19)$ \\
\hline Yes & 1.00 & 1.00 & 1.00 & 1.00 & 1.00 & 1.00 \\
\hline Paid work & $p<0.001$ & $p=0.001$ & $p<0.001$ & $p<0.001$ & $p<0.001$ & $p<0.001$ \\
\hline No & $1.24(1.14-1.36)$ & $1.19(1.08-1.31)$ & $1.27(1.19-1.36)$ & $1.24(1.14-1.33)$ & $1.12(1.07-1.18)$ & $1.12(1.07-1.18)$ \\
\hline Yes & 1.00 & 1.00 & 1.00 & 1.00 & 1.00 & 1.00 \\
\hline Income per capita (in quartiles) & $\mathrm{p}<0.001^{*}$ & $\mathrm{p}<0.001^{*}$ & $\mathrm{p}<0.001^{*}$ & $p<0.001^{*}$ & $p=0.010^{*}$ & $p=0.460$ \\
\hline Up to 104 & $1.55(1.39-1.73)$ & $1.31(1.15-1.50)$ & $1.43(1.31-1.56)$ & $1.21(1.10-1.34)$ & $1.09(1.02-1.16)$ & $1.06(0.98-1.14)$ \\
\hline 105-188 & $1.14(1.01-1.29)$ & $1.13(0.98-1.32)$ & $1.11(1.01-1.22)$ & $1.06(0.95-1.19)$ & $0.96(0.90-1.03)$ & $1.01(0.93-1.09)$ \\
\hline $189-300$ & $1.06(0.94-1.20)$ & $1.02(0.89-1.16)$ & $1.10(1.01-1.21)$ & $1.06(0.96-1.17)$ & $1.00(0.94-1.06)$ & $1.01(0.95-1.08)$ \\
\hline 301 or more & 1.00 & 1.00 & 1.00 & 1.00 & 1.00 & 1.00 \\
\hline Adequacy of the structure & $\mathrm{p}<0.001^{*}$ & $p=0.009^{*}$ & $\mathrm{p}<0.001^{*}$ & $p=0.018^{*}$ & $p<0.001^{*}$ & $\mathrm{p}<0.001^{*}$ \\
\hline Inadequate & $1.55(1.34-1.80)$ & $1.33(1.12-1.58)$ & $1.35(1.20-1.51)$ & $1.21(1.06-1.39)$ & $1.34(1.23-1.46)$ & $1.19(1.09-1.30)$ \\
\hline Less adequate & $1.18(1.08-1.29)$ & $1.05(0.95-1.17)$ & $1.13(1.06-1.20)$ & $1.05(0.97-1.13)$ & $1.17(1.12-1.23)$ & $1.11(1.05-1.17)$ \\
\hline Adequate & 1.00 & 1.00 & 1.00 & 1.00 & 1.00 & 1.00 \\
\hline Adequacy of the process & $\mathrm{p}<0.001^{*}$ & $p=0.001^{*}$ & $\mathrm{p}<0.001^{*}$ & $\mathrm{p}<0.001^{*}$ & $\mathrm{p}<0.001^{*}$ & $\mathrm{p}<0.001^{*}$ \\
\hline Inadequate & $1.40(1.23-1.59)$ & $1.27(1.10-1.48)$ & $1.34(1.21-1.48)$ & $1.26(1.12-1.41)$ & $1.52(1.41-1.63)$ & $1.45(1.35-1.56)$ \\
\hline Less adequate & $1.15(1.05-1.26)$ & $1.12(1.01-1.24)$ & $1.15(1.08-1.24)$ & $1.14(1.05-1.23)$ & $1.25(1.19-1.32)$ & $1.23(1.16-1.29)$ \\
\hline Adequate & 1.00 & 1.00 & 1.00 & 1.00 & 1.00 & 1.00 \\
\hline
\end{tabular}

PMAQ: Program for Improving Access and Quality of the Primary Care; MHDI: Municipal Human Development Index; FHS: Family Health Strategy; PR: prevalence ratio

* p-value: Wald test for linear trend. 


\section{DISCUSSION}

In this study, of the women aged between 25 and 64 years in 2012, users of primary care services in Brazil, 93.3\% performed Pap smear at least once in their lives and $88.8 \%$ reported an updated examination, reaffirming a significant improvement in the access to cervical cancer screening, already indicated by a previous study ${ }^{12}$. Although the performance of primary care exceeds the parameters of the $\mathrm{WHO}^{26}$, the high prevalence of quality indicators for screening does not indicate the full solution of the problems in the country. In addition, our study encompasses users of the FHS, whose performance is better than that of traditional basic services ${ }^{4}$.

The lack of access throughout life, late examination, and lack of guidance vary according to contextual and individual characteristics, in addition to the characteristics of health services, although relatively by little. On the other hand, one in fifteen women aged between 25 and 64 years linked to services of primary health care in Brazil had never performed Pap smear. This missed care opportunity arises from, among other aspects, problems in the work structure and process of the BHU, as previously observed in studies on the performance of $\mathrm{FHS}^{4,24}$.

The problems in the quality of the screening increased because of the decrease in HDI, a contextual characteristic that expressed the greatest difference in relation to the three outcomes studied. The finding coincides with other Brazilian studies suggesting a lower capacity for health investment in poorer municipalities, which concentrate a larger proportion of vulnerable social groups ${ }^{6,24}$. The VIGITEL $(2011)^{19}$ has also found strong positive correlation between the rate of Pap smear at some time in life and in the last three years and the HDI of the municipalities studied.

The increase in population size of the municipality and FHS coverage was associated with an increase of the problems in the quality of the screening. Large urban centers have better economic conditions, greater capacity of investment, and higher qualification of health teams ${ }^{25}$. However, after adjusted analysis, this was not reflected in the quality of cervical cancer screening in the primary health care network, in contrast to findings from population-based studies, such as the World Health Survey (WHS), carried out in Brazil, in 2003. That study included users of the SUS and the private sector, showing a marked social gradient in the coverage of the Pap smear and a lower percentage of examination carried out more than 36 months before, as the population size of the municipalities decreased ${ }^{22,23}$. In the crude analysis, our finding was similar to that of the WHS; however, when controlling for the socioeconomic differences between the sizes of municipalities, there was a reversal of the pattern, indicating greater difficulty of large municipalities in ensuring the provision of quality services. Other studies ${ }^{11,25}$ also highlight barriers in the performance of primary care in large municipalities resulting from, for example, the urbanization profile. Large social inequalities and poor population concentration can be observed, particularly in metropolitan regions, along with an inequitable distribution and organizational problems of the services, possibly implying longer and costly trips for users.

The increase in the prevalence of poor quality indicators for cervical cancer screening from the increase in municipal FHS coverage is consistent with the findings related to HDI, given the greater presence of this care model in poorer areas and municipalities. A study carried out in 2006 already indicated greater FHS coverage in poorer municipalities, from their orientation for the care of the most vulnerable populations and territories ${ }^{4}$. However, similar to that observed in the adjusted analysis, in which the lack of access throughout life is no longer associated with FHS coverage, investments in the qualification of this model of care show a great potential to promote health equity in Brazil ${ }^{4}$.

The South region had less problems of screening in the primary care network, while the Midwest had more problems, signaling a greater complexity of regional inequalities in the quality of the Pap smear ${ }^{3}$. The finding regarding the better screening quality in the South and Southeast regions when compared to the other areas is coherent with several studies $^{4,5,24}$. The apparent surprise comes from the worst screening situation in the Midwest, 
even when compared to the North and Northeast regions. The explanation for the finding is challenging and this study does not exhaust it, but a consideration seems relevant and closely related to the arguments concerning large urban centers. The Midwest is the second most urbanized region in the country, with almost $90 \%$ of the population living in cities, and the Federal District (97\%) is the Federation Unit with the highest rate of urbanization in the country, together with Rio de Janeiro ${ }^{8}$. The process of urbanization in the Midwest produced a rapid concentration of slums and poor and disorganized areas on the outskirts of the cities of the region, which did not have time to accumulate the infrastructure observed in the municipalities of the South and Southeast regions, including in relation to health equipment ${ }^{8,25}$. In addition, the evidence indicates a more equitable pattern in performing Pap smear in the North and Northeast regions, when compared to the Midwest ${ }^{20,21}$.

The quality issues of the screening were higher in users aged 25 to 35 years and 50 to 64 years. Martins et al. ${ }^{14}$ highlight that younger women do not perform the examination as frequently as older women. Thus, focus on this group would produce a historic effect of increased coverage of the screening. The incidence of cervical cancer increases between 30 and 39 years of age, reaching its peak from the fifth decade of life, which should guide the initiatives of the BHU to perform screening, especially among older women. In Brazil, Amorim et al. ${ }^{1}$ have analyzed the prevalence of no Pap smear testing according to socioeconomic and demographic variables and the variables related to health behaviors, in women aged 40 years or more, living in the municipality of Campinas, State of São Paulo, Brazil, highlighting the age group of 40 to 59 years as one of the factors associated with no examination.

White women had the lowest prevalence for the three indicators of low quality of cervical cancer screening, even after the adjusted analysis, coinciding with several studies carried out in Brazil ${ }^{1,10,14}$. The reasons underlying the relative advantage of white users in relation to the other races may be related to adjustment, given the difficulty of accurately measuring family income. In addition, they may be related to cultural and behavioral characteristics related to both users (adherence to screening) and services (different reception of users based on race). Women with a partner who lived in households with four or five persons also had lower prevalence for the three outcomes, similar to that observed in other studies ${ }^{1,10}$. These variables are also markers of socioeconomic conditions and the conditions of facilities or support for the examination.

Women who received the Bolsa Família benefit had lower prevalence of lack of access for the examination and lack of guidance. The benefit seems to positively influence the access to and quality of the examination, similar to the positive effect found in the reduction of infant mortality ${ }^{18}$. This result indicates a possible compensatory effect of this income transfer strategy in favor of equity, since the women who receive the benefit present greater social vulnerability ${ }^{13}$.

In this study, users with paid work and living in households with higher per capita income had fewer problems in the quality of the screening, indicating social inequity in cervical cancer prevention in primary health care. A study conducted based on data from the Pesquisa Nacional por Amostra de Domicílios (PNAD - National Household Sample Survey) of 2008 confirmed the higher number of Pap smear examinations in higher income quintiles ${ }^{21}$. Socioeconomic inequality in the access to the examination was also observed in other publications ${ }^{11,16}$.

In addition, the quality of the screening by Pap smear improved according to the adequacy of the work structure and process in the BHU. The results of the assessment of the quality of cervical cancer screening in Brazil reaffirm the relevance of adequate work structures and processes to improve the performance of services, as classically highlighted by Donabedian². In this sense, investments in the primary care network are essential not only to improve the performance of services, but also to promote social equity in health, considering that the adequacy of the work structure and process reduced the probability of occurrence of all indicators of low quality for cervical cancer screening. This is certainly one of the most relevant findings of the study, considering its potential to subsidize policies aimed at improving the prevention of cervical cancer and its meaning for more equitable health conditions for the population that uses basic health services, particularly the FHS. The 
finding is also relevant to guide the training and qualification of health professionals in undergraduate and graduate courses.

Among the limitations of this study, we highlight the assessment of health teams that voluntarily joined the PMAQ, which may overestimate the performance of services compared to other health teams. The location of the users interviewed in the health team itself suggests that the prevalence of low quality could be higher in the case of a population-based assessment. On the other hand, the voluntary adherence of teams allowed us to know the possible standard of excellence of the Brazilian primary health care, being a parameter for future comparisons in the next PMAQ cycles, in relation to other services of the SUS or the private sector. We also highlight the great magnitude of the sample of users and the national scope of the study, allowing comparisons between the regions, municipalities, and characteristics of users. The percentage of information loss for the studied variables was small, except for the variable of per capita income, thus reinforcing the internal validity and facilitating a more detailed comparison of the three selected outcomes for the characterization of the problems in the quality of cervical cancer screening.

The quality of the Pap smear, although improved with the adequacy of the work structure and process in the BHU, strongly depends on the social characteristics of the context and the population studied. It is worth highlighting the greater access and greater guidance for the examination in beneficiaries of the Bolsa Familia Program. In short, investments in both the work structure and process of the BHU, as well as in social programs of income transfer and progress of social conditions of the population, are essential to improve the quality of the program of cervical cancer screening in Brazil.

\section{REFERENCES}

1. Amorim VMSL, Barros MBA, César CLG, Carandina L, Goldbaum M. Fatores associados à não realização do exame de Papanicolaou: um estudo de base populacional no município de Campinas, São Paulo, Brasil. Cad Saude Publica. 2006;22(11):2329-38. https://10.1590/S0102-311X2006001100007

2. Donabedian A. The quality of care: how can it be assessed? JAMA.1988;260(12):1743-8. https://doi.org/10.1001/jama.1988.03410120089033

3. Duarte EC, Schneider MC, Sousa RP, Ramalho WM, Sardinha LV, Silva Júnior JB, et al. Epidemiologia das desigualdades em saúde no Brasil: um estudo exploratório. Brasília (DF): Organização Pan-Americana da Saúde; 2002 [cited 2017 Mar 12]. Available from: http://repositorio.unb.br/bitstream/10482/12955/1/LIVRO_EpidemologiaDesigualdades.pdf

4. Facchini LA, Piccini RX, Tomasi E, Thumé E, Silveira DS, Siqueira FV, et al. Desempenho do PSF no Sul e no Nordeste do Brasil: avaliação institucional e epidemiológica da Atenção Básica à Saúde. Cienc Saude Coletiva. 2006;11(3):669-81. https://doi.org/10.1590/S1413-81232006000300015

5. Facchini LA, Thumé E, Nunes BP, Silva SM, Fassa AG, Garcia LP, et al. Governance and health system performance: national and municipal challenges to the Brazilian Family Health Strategy. In: Reich MR, Takemi K, editors. Governing health systems: for nations and communities around the world. Brookline: Lamprey \& Lee; 2015. p.203-36

6. Henrique F, Calvo MCM. Grau de implantação do Programa Saúde da Família e indicadores sociais. Cienc Saude Coletiva. 2009;14 Supl 1:1359-65. https://doi.org/10.1590/S1413-81232009000800008

7. Instituto Brasileiro de Geografia e Estatística. Panorama da saúde do Brasil: acesso e utilização dos serviços, condições de saúde e fatores de risco e proteção à saúde (PNAD, 2008). Rio de Janeiro: IBGE; 2010 [cited 2017 Mar 12]. Available from: http://bvsms.saude.gov.br/bvs/ publicacoes/pnad_panorama_saude_brasil.pdf

8. Instituto Brasileiro de Geografia e Estatística. Censo demográfico 2010. Rio de Janeiro: IBGE; 2012 [cited 2017 Mar 12]. Available from: http://www.ibge.gov.br/home/estatistica/populacao/censo2010/

9. Instituto Nacional de Câncer (BR), Coordenação de Prevenção e Vigilância. Estimativa 2016-2017: incidência de câncer no Brasil. Rio de Janeiro: INCA; 2015 [cited 2017 Mar 12]. Available from: http://www.inca.gov.br/wcm/dncc/2015/estimativa-2016.asp 
10. Leal MC, Gama SGN, Frias P, Szwarcwald CL. Healthy lifestyles and access to periodic health exams among Brazilian women. Cad Saude Publica. 2005;21 Suppl.1):S78-8. https://10.1590/S0102-311X2005000700009

11. Machado CV, Lima LD, Viana LS. Configuração da atenção básica e do Programa Saúde da Família em grandes municípios do Rio de Janeiro, Brasil. Cad Saude Publica. 2008;24 Supl 1:s42-57. https://10.1590/S0102-311X2008001300010

12. Malta DC, Jorge AO. Análise de tendência de citologia oncótica e mamografia das capitais brasileiras. Cienc Cult. 2014 [cited 2017 Mar 12];66(1):25-9. Available from: http://cienciaecultura.bvs.br/pdf/cic/v66n1/a12v66n1.pdf

13. Martins APB, Canella DS, Baraldi LG, Monteiro CA. Transferência de renda no Brasil e desfechos nutricionais: revisão sistemática. Rev Saude Publica. 2013;47(6):1159-71. https://doi.org/10.1590/S0034-8910.2013047004557

14. Martins LFL, Thuler LCS, Valente JG. Cobertura do exame de Papanicolaou no Brasil e seus fatores determinantes: uma revisão sistemática da literatura. Rev Bras Ginecol Obstet. 2005;27(8):485-92. https://doi.org/10.1590/S0100-72032005000800009.

15. Ministério da Saúde (BR), Secretaria de Vigilância em Saúde, Departamento de Análise de Situação de Saúde. Plano de ações estratégicas para o enfrentamento das doenças crônicas não-transmissíveis (DCNT) no Brasil 2011-2022. Brasília (DF): Ministério da Saúde; 2011 [cited 2017 Mar 12]. (Série B. Textos Básicos de Saúde). Available from: http://bvsms. saude.gov.br/bvs/publicacoes/plano_acoes_enfrent_dent_2011.pdf

16. Murata IMH, Gabrielloni MC, Schirmer J. Cobertura do Papanicolaou em mulheres de 25 a 59 anos de Maringá - PR, Brasil. Rev Bras Cancerol. 2012 [cited 2017 Mar 12];58(3):409-15. Available from: http://www.inca.gov.br/rbc/n_58/v03/pdf/10_artigo_cobertura_papanicolaou_ mulheres_25_59_anos_maringa_pr_brasil.pdf

17. Quadros CAT, Victora CG, Costa JSD. Coverage and focus of a cervical cancer prevention program in southern Brazil. Rev Panam Salud Publica. 2004;16(4):223-32. https://doi.org/10.1590/S1020-49892004001000001

18. Raselle D, Aquino R, Santos CAT, Paes-Souza R, Barreto ML. Effect of a conditional cash transfer programme on childhood mortality: a nationwide analysis of Brazilian municipalities. Lancet. 2013;382(9886):57-64. https://doi.org/10.1016/ S0140-6736(13)60715-1

19. Sadovsky ADI, Poton WL, Reis-Santos B, Barcelos MRB, Silva ICM. Índice de Desenvolvimento Humano e prevenção secundária de câncer de mama e colo do útero: um estudo ecológico. Cad Saude Publica. 2015;31(7):1539-50. https://doi.or/10.1590/0102-311X00073014

20. Santos RS, Melo ECP, Santos KM. Análise espacial dos indicadores pactuados para o rastreamento do câncer do colo do útero no Brasil. Texto Contexto Enferm. 2012;21(4):800-10. https://doi.org/10.1590/S0104-07072012000400010

21. Silva NC, Rocha TAH, Rodrigues RB, Barbosa ACQ. Equidade na atenção primária à saúde da mulher: uma análise do Brasil e suas regiões. Rev Baiana Saude Publica. 2014;38(2):243-65. https://doi.org/10.5327/Z0100-0233-2014380200003

22. Szwarcwald CL, Leal MC, Gouveia GC, Souza WV. Desigualdades socioeconômicas em saúde no Brasil: resultados da Pesquisa Mundial de Saúde, 2003. Rev Bras Saude Mater Infant. 2005;5 Supl 1:s11-22. https://doi.org/10.1590/S151938292005000500002

23. Szwarcwald CL, Viacava F. Pesquisa Mundial de Saúde: aspectos metodológicos e articulação com a Organização Mundial da Saúde. Rev Bras Epidemiol. 2008;11Supl 1:58-66. https://doi.org/10.1590/S1415-90X2008000500006

24. Tomasi E, Oliveira TF, Fernandes PAA, Thumé E, Silveira DS, Siqueira FV, et al. Estrutura e processo de trabalho na prevenção do câncer de colo do útero na Atenção Básica à Saúde no Brasil: Programa de Melhoria do Acesso e da Qualidade - PMAQ. Rev Bras Saude Mater Infant. 2015;15(2):171-80. https://doi.org/10.1590/S1519-38292015000200003

25. Viana ALA, Rocha JSY, Elias PE, Ibañez N, Novaes MHD. Modelos de atenção básica nos grandes municípios paulistas: efetividade, eficácia, sustentabilidade e governabilidade. Cienc Saude Coletiva. 2006;11(3):577-606. https://doi.org/10.1590/S1413-81232006000300009

26. World Health Organization. Cancer control: knowledge into action: WHO guide for effective programmes. Geneva: WHO; 2007 [citado 2 abr 2009]. Disponível em: www.who.int/cancer/ modules/Prevention\%20Module.pdf 
27. World Health Organization. Early Detection. Cancer control: knowledge into action: WHO guide for effective programs; module 3. Geneva: WHO; 2007 [cited 2016 Feb 27]. Available from: http://screening.iarc.fr/doc/Early\%20Detection\%20Module\%203.pdf

28. World Health Organization, International Agency for Research on Cancer. Globocan 2012. Lyon: IARC; 2012 [cited 2016 Feb 27]. Available from: http://globocan.iarc.fr/

Funding: Coordenação de Aperfeiçoamento de Pessoal de Nível Superior (CAPES - Process 23038.004019/2014-15). Conselho Nacional de Desenvolvimento Científico e Tecnológico (CNPq - Process 234337/2014-1).

Authors' Contribution: Design, planning, collection, analysis, and interpretation of the data of the study: MRBB, LAF, SMSD, and BPN. Writing of the study: MRBB. Review, approval of the final version, and public responsibility for the content of the article: all authors.

Acknowledgments: To doctors Timothy R. Rebbeck and Malgorzata N. Chalupowski, for the technical and scientific assistance for the presentation of this study at "The Harvard Chan PDA Fall 2015 Travel Award" "Joint Symposium of the Dana-Farber/Harvard Cancer Center Programs in Breast and Gynecologic Cancers", "2016 Poster Day", and "2016 Epidemiology Congress of the Americas".

Conflict of Interest: The authors declare no conflict of interest. 